\title{
Fibre digestibility, abundance of faecal bacteria and plasma acetate concentrations in overweight adult mares
}

\author{
Megan L. Shepherd ${ }^{1}$, Monica A. Ponder ${ }^{2}$, Amy O. Burk ${ }^{3}$, Stewart C. Milton ${ }^{1}$ and William S. Swecker Jr ${ }^{1}$ \\ ${ }^{1}$ Department of Large Animal Clinical Sciences, Virginia-Maryland Regional College of Veterinary Medicine, Virginia Tech, Duck Pond Drive \\ (0442), Blacksburg, VA 24061, USA \\ ${ }^{2}$ Department of Food Science and Technology, Virginia Tech, Blacksburg, VA 24061, USA \\ ${ }^{3}$ Department of Animal and Avian Sciences, University of Maryland, College Park, MD 20742, USA
}

(Received 12 September 2013 - Final revision received 10 February 2014 - Accepted 4 March 2014)

Journal of Nutritional Science (2014), vol. 3, e10, page 1 of 11

doi:10.1017/jns.2014.8

Abstract

The purpose of the present study was to compare digestibility of grass hay, faecal and plasma volatile fatty acid (VFA) concentrations, and faecal bacterial abundance in overweight and moderate-condition mares. Five overweight adult mixed-breed mares and five adult mixed-breed mares in moderate condition were housed individually and limit-fed orchard grass (Dactylis glomerata) hay at $20 \mathrm{~g} / \mathrm{kg}$ body weight (as fed) daily for $14 \mathrm{~d}$. Forage DM and fibre digestibility were determined using AOAC methods; digestible energy was measured using bomb calorimetry; plasma and faecal VFA concentrations were determined by use of GC and MS; faecal Firmicutes, Bacteroidetes, Fibrobacter succinogenes, Ruminococcus flavefaciens and total bacteria abundance was determined by quantitative real-time PCR using previously designed phylum-specific 16S ribosomal RNA gene primers. No differences in hay digestibility, faecal VFA concentrations or faecal bacterial abundance were detected between overweight and moderate-condition mares. Mean plasma acetate concentrations were higher $(P=0.03)$ in overweight $(1.55$ (range 1.43-1.65) mmol/l) $v$. moderate-condition (1.39 (range 1.22-1.47) mmol/l) mares. We conclude that the higher plasma acetate in overweight mares should be further investigated as a potential link between gut microbes and obesity in horses.

Key words: Body condition score: Digestible energy: Faecal bacteria: Horses

A total of $51 \%$ of adult horses in southwest Virginia state, USA, are overweight or obese ${ }^{(1)}$ and with similar findings in Scotland ${ }^{(2)}$ and the $\mathrm{UK}^{(3)}$, the rate of obesity may be similar in other equine populations. Obesity is a critical problem for the horse population due to the many negative downstream effects on health, welfare and performance. Negative health effects of obesity in horses include reduced reproductive performance ${ }^{(4,5)}$, reduced evaporative cooling and reduced athletic performance ${ }^{(6)}$, and insulin resistance ${ }^{(7-9)}$. The latter increases the risk of laminitis, a painful and debilitating condition of the equine hoof ${ }^{(10,11)}$.

Many factors influence the development of an overweight and obese state, but, simply, weight gain occurs when a surplus of energy is consumed relative to energy utilisation. Interestingly, Thatcher et al. ${ }^{(1)}$ reported that the obese horses in the southwest Virginia study were consuming a foragebased diet, suggesting that horses are becoming overweight and obese on forage alone and not necessarily highly digestible commercial feeds and grains. Forage is high in fibre, which is not digested by mammalian enzymes due to the $\beta$-glycosidic bonds linking monosaccharide residues; however, fibres are digested by micro-organisms in the gastrointestinal tract (also known as gut microbes or gut microbiota), specifically the caecum and colon, of the horse ${ }^{(12)}$. These gut microbes produce usable products (i.e. volatile fatty acids; VFA) from otherwise indigestible substrates. Acetate is the dominant VFA produced

Abbreviations: ADF, acid-detergent fibre; BCS, body condition score; DE, digestible energy; DMI, DM intake; NDF, neutral-detergent fibre; OG, orchard grass; rDNA, ribosomal DNA; rRNA, ribosomal RNA; VFA, volatile fatty acid.

* Corresponding author: Dr Megan L. Shepherd, fax +1 540231 6448, email meshephe@vt.edu 
by equine gut microbes ${ }^{(13-17)}$. Diet and diet change influence faecal VFA concentrations in horses in that the acetate:propionate ratio is generally lower with increasing grain starch in the $\operatorname{diet}^{(17,18)}$. Furthermore, Julliand et al. ${ }^{(19)}$ reported that the concentration of fibrolytic bacteria and acetate production were lower in the caecum and colon of horses fed hay plus barley $v$. horses fed hay alone.

Obese humans and rodents appear to have a unique gut microbiota as compared with their lean counterparts ${ }^{(20,21)}$. Conventionally raised mice (those with gut microbes) have greater diet-induced weight gain than their germ-free (those without gut microbes) mouse counterparts ${ }^{(22,23)}$. Furthermore, Turnbaugh et al. ${ }^{(2)}$ reported that obese mice $(o b / o b)$ have higher caecal acetate concentrations than nonobese wild-type mice. The role of VFA such as acetate on fat mass may be two-fold: VFA serve as an energy source and as ligands for $G$ protein-coupled receptors with subsequent inhibition of lipolysis and stimulation of adipogenesis $^{(25,26)}$. In horses, plasma acetate may be aerobically oxidised and directly used for energy ${ }^{(27)}$ or stored as TAG in adipose and skeletal tissue ${ }^{(28)}$.

The equine gut microbiota has received increasing attention due to the importance of gut microbes in equine health. The Firmicutes phylum dominates the hindgut (caecum and large colon) and faecal microbiome in horses (44-72\% of total bacteria) ${ }^{(29,30)}$. The abundance of Bacteroidetes in horses varies between 4 and $49 \%$ of total bacteria ${ }^{(31-33)}$. In obese mice, pigs and human subjects there is an association between increased relative abundance of the Firmicutes phylum, along with a reduction in the relative abundance of the Bacteroidetes phylum ${ }^{(20,21,34-36)}$. While this is an area of controversy due to the inconsistency in abundance of these two phyla in obese $v$. lean individuals, there is also variation between studies with respect to host species, samples evaluated (i.e. faecal $v$. intestine lumen $v$. intestinal mucosa), region of the gastrointestinal tract evaluated, and time point relative to obesity ${ }^{(37,38)}$. Nevertheless, these phyla continue to be associated with obesity in recent studies ${ }^{(39,40)}$ and have not yet been evaluated relative to obesity in the horse.

The equine hindgut microbiome is dominated by fibrolytic bacteria according to both culture-based ${ }^{(41,42)}$ and cultureindependent studies ${ }^{(43,44)}$. Fibrolytic bacteria are represented in both the Firmicutes and Bacteroidetes phyla ${ }^{(45)}$. Fibrobacter succinogenes, Ruminococcus flavefaciens and $\mathrm{R}$. albus are the most extensively studied fibrolytic bacteria in herbivores ${ }^{(43,44,46)}$ and, of these, F. succinogenes and R. flavefaciens represent 12 and $4 \%$, respectively, of total hindgut bacteria in the horse $\mathrm{e}^{(43,44,47)}$. Due to their role in breaking down the most abundant carbohydrate in the forage-based equine diet, these bacterial species may play a causative role in the condition of equine obesity or overweight. Despite the interest in equine obesity $^{(8,9,48,49)}$ and reliance on gut microbes for energy harvest, no studies to date have compared the abundance of Firmicutes, Bacteroidetes or fibrolytic bacteria in overweight $v$. moderate-condition mares.

A relationship between gut microbes or microbial products with obesity would be significant as hindgut microbes can provide more than $50 \%$ of daily digestible energy (DE) requirements to a horse $\mathrm{e}^{(16,27,50)}$, as compared with only $10 \%$ of the energy requirements of humans ${ }^{(51-55)}$. Alterations in the gut microbiota or changes in function of the gut microbes, such as enhanced VFA production, may influence body weight or adiposity in the horse despite similar energy consumption. In the present study, we assessed the in vivo diet digestibility of grass hay in overweight and moderatecondition mares. In addition, faecal and plasma VFA concentrations were measured to evaluate primary metabolic outputs of hindgut microbial fibre fermentation. Finally, abundance of members of the Firmicutes and Bacteroidetes phyla and the abundance of the fibrolytic bacteria R. flavefaciens and F. succinogenes in the faeces were measured. We evaluated the ratio of active, fibrolytic ${ }^{(56)}$ R. flavefaciens and F. succinogenes (16S ribosomal RNA (rRNA)) $v$. the total number of fibrolytic bacterial copies (16S ribosomal DNA (rDNA)) abundance, providing a measurement of the proportion of actively replicating bacteria. We hypothesised that overweight mares would have higher apparent hay digestibility and higher faecal and plasma acetate concentrations than moderate-condition mares. We also hypothesised that overweight mares will have an increased abundance of faecal Firmicutes and a lower abundance of Bacteroidetes. Furthermore, we expected overweight mares to have a higher abundance of active $R$. flavefaciens and $F$. succinogenes compared with moderate-condition mares.

\section{Materials and methods}

\section{Animals and housing}

A total of five moderate-condition adult, non-pregnant mares (body condition score (BCS) 5-6 on a nine-point scale ${ }^{(57)}$; age 7-20 years; weight $523-611 \mathrm{~kg}$ ) and five overweight adult, non-pregnant mares (BCS 7-9/9; age 7-20 years; weight $511-575 \mathrm{~kg}$ ) from the Virginia-Maryland Regional College of Veterinary Medicine teaching herd were allocated to the study. The total herd of twenty-two horses had been managed for at least 3 years, grouped by BCS and managed on the same pastures (rotated around cool-season grass pastures) and fed the same cool-season grass hay during winter months. Forage was fed at a rate to meet National Research Council ${ }^{(58)}$ daily DE requirements for ideal body weight. The overweight mares maintained a BCS $>$ $6 / 9$ throughout the year and the moderate-condition mares maintained a BCS $<6 / 9$ throughout the year. Average BCS at the start of the study for the overweight and moderatecondition groups were $7 \cdot 3 / 9$ and $5 \cdot 3 / 9$, respectively. The study was designed to detect a 0.03 difference \pm $0.015 \mathrm{SD}^{(59)}$ in digestibility based on $\alpha$ of 0.05 and $1-\beta$ of 0.885 .

Mares were housed in individual box stalls $(3.6 \mathrm{~m} \times 3.6 \mathrm{~m})$ with adjacent individual dry paddocks $(3.6 \mathrm{~m} \times 4.8 \mathrm{~m})$ during the $15 \mathrm{~d}$ study. The study was divided into two periods: a $10 \mathrm{~d}$ acclimatisation period followed by a $4 \mathrm{~d}$ digestibility trial and a final day for morphometric measurements. For the first $10 \mathrm{~d}$ of the study, stalls were bedded with pine shavings and 
mares had access to paddocks $24 \mathrm{~h}$ per d. Stalls were cleaned twice daily (11.00 and 20.00 hours). For the last $5 \mathrm{~d}$ of the study, stalls were bare except for rubber mats; mares had access to outside paddocks $10-15$ min once daily during the 11.00-hour thorough stall cleaning; faeces were accounted for as described below.

All horses received routine veterinary care including vaccines, deworming and dental floating before the study. The study was conducted during June 2011 in Blacksburg, VA (mean ambient temperature $22 \cdot 1^{\circ} \mathrm{C}$ ). The animals were maintained and all procedures were performed in accordance with the Virginia Tech Institutional Animal Care and Use Committee (IACUC) guidelines (IACUC no. 10-152-CVM).

\section{Diet}

Before the study, all mares were housed on and allowed ad libitum access to the same cool-season grass (predominantly tall fescue; Festuca arundinacea) pastures all year round. Mares were fed cool-season grass hay (predominantly orchard grass (OG; Dactylis glomerata) hay) in the winter months when pasture forage was unavailable. Mares were housed in individual stalls during the study (days 0-15) and limit-fed a commercially available OG hay (Standlee Hay Company) (Table 1). Hay was fed in hay nets at $20 \mathrm{~g} / \mathrm{kg}$ body weight as fed per d divided into two equal feedings at 08.00 and 20.00 hours. The mares were acclimatised to the hay during a $10 \mathrm{~d}$ acclimatisation period, as previously described ${ }^{(60)}$. Mares were offered a vitamin-mineral supplement (EquiMin ${ }^{\circledR}$ Granular; Southern States) free choice, as previously fed on pasture; the supplement was withdrawn on days 11-15. Orts were weighed,

Table 1. Nutrient analysis* of the orchard grass (Dactylis glomerata) hay fed to mares during the study

\begin{tabular}{|c|c|c|}
\hline Analyte & $\begin{array}{c}\text { Orchard grass } \\
\text { hay }\end{array}$ & $\begin{array}{c}\text { Equi-analytical reference } \\
\text { interval } \dagger\end{array}$ \\
\hline $\begin{array}{l}\text { DM ( } g / 100 \mathrm{~g} \text { as } \\
\text { fed) }\end{array}$ & 92.4 & $90 \cdot 6-93 \cdot 3$ \\
\hline \multicolumn{3}{|l|}{ Digestible energy } \\
\hline $\mathrm{MJ} / \mathrm{kg} \mathrm{DM}$ & 8.46 & $7 \cdot 54-9 \cdot 21$ \\
\hline Mcal/kg DM‡ & 2.02 & $1 \cdot 8-2 \cdot 2$ \\
\hline CP (g/100 g DM) & 14.5 & $6 \cdot 9-14 \cdot 7$ \\
\hline ADF (g/100 g DM) & 41.7 & $34.4-43.6$ \\
\hline NDF ( $g / 100 \mathrm{~g} \mathrm{DM})$ & $62 \cdot 8$ & $56 \cdot 5-69.9$ \\
\hline WSC (g/100 g DM) & 5.8 & $6 \cdot 5-15 \cdot 2$ \\
\hline ESC (g/100 g DM) & 2.9 & $4 \cdot 6-10 \cdot 3$ \\
\hline $\begin{array}{l}\text { Starch }(g / 100 \mathrm{~g} \\
\text { DM) }\end{array}$ & 0.4 & $0.9-3.7$ \\
\hline $\begin{array}{l}\text { NSC }(g / 100 \mathrm{~g} \\
\text { DM)§ }\end{array}$ & $6 \cdot 2$ & $8 \cdot 0-17 \cdot 7$ \\
\hline Ca (g/100 g DM) & 0.46 & $0.3-0.7$ \\
\hline$P(g / 100$ g DM) & 0.45 & $0.2-0.3$ \\
\hline
\end{tabular}

$\mathrm{CP}$, crude protein; ADF, acid-detergent fibre; NDF, neutral-detergent fibre; WSC, water-soluble carbohydrates (monosaccharides, dissacharides, fructan oligo/polysaccharides); ESC, ethanol-soluble carbohydrates (monosaccharides, disaccharides); NSC, non-structural carbohydrates.

${ }^{*}$ Forage analysis performed was as previously described ${ }^{(33)}$; values include a single measurement on a composite sample.

† Equi-Analytical Laboratories; grass hay analyte reference range is mean $\pm 1 \mathrm{SD}$ for 10000-40000 samples based on analyte.

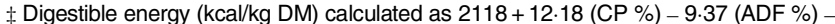
3.83 (hemicellulose \%) +47.18 (fat \%) +20.35 (NSC) -26.3 (ash \%) ${ }^{(93)}$.

$\S$ NSC $($ calculated $)=$ WSC + starch. recorded and subtracted from the daily amount of hay offered. Total daily DM intake (DMI) was determined for each mare by multiplying total hay intake by average hay DM.

\section{Sample collection}

On day 0 and day 15, mares were body condition scored, weighed on a digital scale (Cambridge Scale Works) and assessed for subcutaneous fat (rump fat) thickness before the 08.00 hours feeding. $\mathrm{BCS}^{(57)}$ was subjectively scored on day 0 and day 15 by a single individual (M. L. S.). Rump fat thickness was measured with a $12 \mathrm{mHz}$ tendon probe with the probe placed in the sagittal plane $5 \mathrm{~cm}$ off of midline at the centre of the pelvis ${ }^{(61)}$; measurements were taken in triplicate and averaged. All measurements were taken before the morning meal; day 0 measurements were taken immediately after transport to the research barn.

A $20 \mathrm{~g}$ hand grab sample of the commercially available OG hay was obtained twice daily at each feeding on days 11-14 and stored in individual brown paper bags until analysis. Total daily faeces were collected continuously throughout the day on days 11-14 into plastic bags, kept closed between collection, to prevent moisture loss of faeces; total collections were weighed four times daily $(14.00,20.00,02.00$ and 08.00 hours) before disposal. Additional three times daily (08.00 09.00, 14.00-15.00, and 20.00-21.00 hours) $200 \mathrm{~g}$ fresh faecal samples, for digestibility and gross energy analysis, were collected into tin mini loaf pans (Schneider Paper Products, Inc.) and placed in a plastic bag until processing within $2 \mathrm{~h}$ of collection. In addition, three $50 \mathrm{~g}$ faecal samples were collected once daily ( 08.00 hours) for VFA and microbial abundance analysis. Two samples were stored in empty $50 \mathrm{ml}$ tubes (VWR International); one sample was stored in a $50 \mathrm{ml}$ tube (VWR International) containing $25 \mathrm{ml}$ RNAlater ${ }^{\circledR}$ (Life Technologies) as per the manufacturer's protocol. The $50 \mathrm{~g}$ faecal sample and $25 \mathrm{ml}$ RNAlater ${ }^{\circledR}$ were manually homogenised immediately after collection. The $50 \mathrm{~g}$ faecal samples were placed immediately on ice, and stored at $-80^{\circ} \mathrm{C}$ within $1 \mathrm{~h}$ of collection until further analysis. All 08.00 hours samples were collected from the rectum; the 14.00 and 20.00 hours samples were collected from the floor immediately after defecation (seconds after defecation was observed).

The $20 \mathrm{~g}$ OG hay samples and $200 \mathrm{~g}$ faecal samples were weighed and dried in a $55^{\circ} \mathrm{C}$ forced-air oven (Precision Freas Mechanical Convection Ovens Model 645; Pacific Combustion) for $96 \mathrm{~h}$ to achieve $<10 \mathrm{~g} / 100 \mathrm{~g}$ moisture. Dried OG hay and faecal samples were ground using a 1-mm screen (model 4 Wiley Mill; Thomas Scientific), composited within horse, and subsampled within horse. All digestibility analyses were evaluated in duplicate. Faecal output was calculated as the summed weight of the four daily total faecal collections and $200 \mathrm{~g}$ three times daily faecal samples for each horse.

Before faecal collection and feeding at 08.00 hours, blood samples were drawn into $10 \mathrm{ml}$ tubes (BD Vacutainer ${ }^{B}$ ) containing lithium heparin for VFA analysis. Plasma was harvested within $30 \mathrm{~min}$ of collection after centrifugation $\left(3000 \mathrm{~g}\right.$ ) and stored at $-80^{\circ} \mathrm{C}$ until analysis. Plasma samples 
were pooled within horse over the four sampling days and analysed for acetate in duplicate.

\section{Apparent digestibility}

In vivo apparent diet $\mathrm{DE}$ digestibility and $\mathrm{DM}$ digestibility are used to represent total-tract digestibility while neutraldetergent fibre (NDF) apparent digestibility and acid-detergent fibre (ADF) apparent digestibility represent microbial fermentation in the hindgut. Gross energy of ground OG hay and faeces was measured with a bomb calorimeter (Parr 1271A Auto Calorimeter) using a sample size of $0 \cdot 15-0 \cdot 20 \mathrm{~g}$ (analysis was corrected for sample weight) and jacket temperature at $30^{\circ} \mathrm{C}$; $1 \mathrm{~g}$ benzoic acid was used as the standard and $0.45-0.50 \mathrm{~g}$ mineral oil was used as the spike. Commercially available OG hay DE for each horse was calculated using the following:

$\mathrm{DE}(\mathrm{kJ} / \mathrm{kg} \mathrm{DM}(\mathrm{kcal} / \mathrm{kg} \mathrm{DM}))=($ gross energy of OG hay $(\mathrm{kJ} / \mathrm{kg} \mathrm{DM}(\mathrm{kcal} / \mathrm{kg} \mathrm{DM})) \times$ total daily hay consumption $(\mathrm{kg}$ $\mathrm{DM}))-($ gross energy faeces $(\mathrm{kJ} / \mathrm{kg} \mathrm{DM}(\mathrm{kcal} / \mathrm{kg} \mathrm{DM})) \times$ total daily faecal production $(\mathrm{kg} \mathrm{DM})$ ).

Data are reported as $\mathrm{kJ} / \mathrm{kg} \mathrm{DM}(\mathrm{kcal} / \mathrm{kg} \mathrm{DM})$. DM, ash, $\mathrm{ADF}$ and NDF, inclusive of ash, were determined using AOAC procedures ${ }^{(62)}$. Apparent digestibility of DM was calculated with the following: DM digestibility $=(\mathrm{DMI}-$ faecal output)/DMI ${ }^{(63)}$; calculations were repeated for organic matter, $\mathrm{NDF}$ and $\mathrm{ADF}$ fractions.

\section{Volatile fatty acids}

Frozen $50 \mathrm{~g}$ faecal samples were thawed at $4^{\circ} \mathrm{C}$ for $4 \mathrm{~h}$ and prepared as described by Otto et al. ${ }^{(64)}$. Briefly, $2 \mathrm{~g}$ of thawed faeces were mixed with $8 \mathrm{ml}$ deionised water and $0.5 \mathrm{ml}$ concentrated $\mathrm{HCl}$ (Fisher-Scientific), vortexed for $10 \mathrm{~s}$, and then centrifuged at $25314 \mathrm{~g}$ for $20 \mathrm{~min}$. The supernatant fraction was filtered through a $0.22 \mu \mathrm{m}$ filter (Millipore Co.) and stored in $3.7 \mathrm{ml}$ (1 fluid dram; DR) glass vials (no. 0333922B; Fisher Scientific). Samples were pooled to combine by day within horse and stored at $-80^{\circ} \mathrm{C}$ until VFA analysis. Thawed pooled plasma and faecal supernatant fraction samples were spiked with $100 \mu \mathrm{l}$ internal standard/volume marker $\left(2 \cdot 5 \mathrm{~mm}-\left[1,2-{ }^{13} \mathrm{C}_{2}\right]\right.$ sodium acetate, $1 \mathrm{~mm}-\left[1,2,3-{ }^{13} \mathrm{C}_{3}\right]$ propionic acid, $1 \mathrm{~mm}-\left[1,2,3,4-{ }^{13} \mathrm{C}_{4}\right]$ sodium butyrate) then derivatised using a water, acetonitrile and 2-chloroethanol solution adapted from Kristensen ${ }^{(65)}$. Faecal preparations were analysed for acetate, propionate and butyrate, and plasma was analysed for acetate by GC and $\mathrm{MS}^{(65)}$.

\section{Faecal bacterial abundance}

Frozen $50 \mathrm{~g}$ faecal samples were thawed at $4^{\circ} \mathrm{C}$ for $4 \mathrm{~h}$ before DNA extraction. A commercial kit (ZR Soil Microbe DNA MicroPrep ${ }^{\mathrm{TM}}$; Zymo Research) was used to extract DNA from $0.25 \mathrm{~g}$ homogenised and pelleted faeces as described by Shepherd $e t a l .{ }^{(30)}$.

Two storage methods (RNAlater ${ }^{\circledR}$-preserved faeces and liquid $\mathrm{N}_{2}$-preserved faeces) and extraction kits (RNeasy ${ }^{\circledR}$ Mini Kit, Qiagen, $\mathrm{Ca}$ and Zymo Soil/Faecal RNA Mini Prep, Zymo Research, Irving, CA) with and without a DNase step were evaluated with the goal of optimising RNA yield and quality from faeces. RNA quality was determined using a Bioanalyser 2100 (Agilent Technologies, Inc.). The highest 23S:16S ratio of 1.5 and RNA integrity number (RIN) of 8.4 , indicators of RNA quality, were obtained from RNA extracted using the RNeasy ${ }^{\circledR}$ Kit (Qiagen) with bead beating and DNase treatment. Furthermore, this method produced the cleanest $23 \mathrm{~S}$ and $16 \mathrm{~S}$ peaks and minimal noise (no additional peaks) on electropherograms. Therefore, RNA was extracted from $0.25 \mathrm{~g}$ of each faecal sample stored in RNAlater ${ }^{\circledR}$ at $-80^{\circ} \mathrm{C}$ after having thawed on ice for $2 \mathrm{~h}$ and strained to remove RNAlater ${ }^{\mathbb{B}}$. The RNeasy ${ }^{\mathbb{B}}$ Mini Kit Fungal/Plant protocol with on-column DNase was followed according to the manufacturer's instructions (Qiagen).

Extracted DNA and RNA concentrations were assessed by spectrophotometry (NanoDrop ND-1000 Spectrophotometer; Coleman Technologies). DNA and RNA was re-extracted from a faecal sample only when concentrations were $<10 \mathrm{ng} /$ $\mu \mathrm{l}$. DNA was standardised to a concentration of $60-70 \mathrm{ng} / \mu \mathrm{l}$; RNA was standardised to a concentration of $65-75 \mathrm{ng} / \mu \mathrm{l}$.

Quantitative real-time PCR was used to quantify the abundance of total bacteria and members of the Firmicutes or Bacteroidetes phylum using previously designed primers (Table 2). Each $25 \mu \mathrm{l}$ reaction contained $12.5 \mu \mathrm{l}$

Table 2. Primers used for determining bacterial abundance

\begin{tabular}{|c|c|c|c|}
\hline Primer/probe and reference & Sequence $\left(5^{\prime} \rightarrow 3^{\prime}\right)$ & Melting temperature $\left({ }^{\circ} \mathrm{C}\right)$ & Target group and standard \\
\hline $926 \mathrm{~F}^{(94)}$ & AAA CTC AAA KGA ATT GAC GG & 49.9 & Universal (Exiguobacterium spp.) \\
\hline $1062 R^{(94)}$ & CTC ACR RCA CGA GCT GAC & $55 \cdot 9$ & \\
\hline Firm928 $\mathrm{F}^{(94)}$ & TGA AAC TYA AAG GAA TTG ACG & 49.9 & Firmicutes (Exiguobacterium spp.) \\
\hline Firm1040 $\mathrm{R}^{(94)}$ & ACC ATG CAC CAC CTG TC & $55 \cdot 2$ & \\
\hline Cfb798 $F^{(94)}$ & CRA ACA GGA TTA GAT ACC CT & 49.9 & Bacteroidetes (Flavobacterium spp.) \\
\hline Cfb967 R $\mathrm{R}^{(94)}$ & GGT AAG GTT CCT CGC GTA T & $54 \cdot 1$ & \\
\hline Universal $\mathrm{F}^{(95)}$ & TCCTACGGGAGGCAGCAGT & $60 \cdot 0$ & Universal \\
\hline Universal - probe ${ }^{(95)}$ & CGTATTACCGCGGCTGCTGGCAC & $60 \cdot 0$ & \\
\hline Universal $\mathrm{F}^{(95)}$ & GGACTACCAGGGTATCTAATCCTGTT & $60 \cdot 0$ & \\
\hline Ruminococcus flavefaciens $\mathrm{F}^{(44)}$ & GTGTCGTGAGATGTTGGGTTAAGT & $60 \cdot 0$ & R. flavefaciens \\
\hline R. flavefaciens - probe $\mathrm{e}^{(44)}$ & CCGCAAAGAGCGCAACCCTT & $60 \cdot 0$ & \\
\hline R. flavefaciens $\mathrm{R}^{(44)}$ & AGTGCTCTTGCGTAGCAACTAAAG & $60 \cdot 0$ & \\
\hline Fibrobacter succinogenes $\mathrm{F}^{(44)}$ & CGTTCCCGGGCCTTGT & $60 \cdot 0$ & F. succinogenes \\
\hline F. succinogenes - probe ${ }^{(44)}$ & CACACCGCCCGTCAAGCCATG & $60 \cdot 0$ & \\
\hline F. succinogenes $\mathrm{R}^{(44)}$ & CACGACTTAGAGCACTCССТTCTC & $60 \cdot 0$ & \\
\hline
\end{tabular}

$F$, forward; $R$, reverse. 
HotStart-IT $^{\circledR}$ SYBR $^{\circledR}$ Green qPCR Master Mix $2 X$ (no. 75770; USB Corp.) with $5 \mathrm{~mm}-\mathrm{MgCl}_{2}, 0.4 \mathrm{~mm}$-nucleotides and $10 \mathrm{~nm}$-fluorescein in addition to $1.3 \mu \mathrm{l}$ each of $16 \mathrm{~S}$ rDNA forward and reverse primers $(10 \mu \mathrm{M}$; Table 2$), 2 \cdot 5 \mu \mathrm{l}$ $10 \%$ dimethyl sulfoxide (Fisher-Scientific), additional $1 \mu \mathrm{l}$ $25 \mathrm{mg} / \mathrm{ml} \mathrm{MgCl}_{2}, 0.5 \mu \mathrm{l} \mathrm{ROX}{ }^{\mathrm{TM}}$ passive reference dye (no. 75768; USB Corp.) and $4.9 \mu \mathrm{l}$ nanopure nuclease-free water (no. E476; Amresco Inc.). The PCR protocol consisted of denaturation at $95^{\circ} \mathrm{C}$ for $3 \mathrm{~min}$ followed by forty cycles of $95^{\circ}$ $\mathrm{C}$ for $15 \mathrm{~s}$, annealing for $30 \mathrm{~s}$ (see annealing temperature in Table 2), and elongation at $72^{\circ} \mathrm{C}$ for $30 \mathrm{~s}$. The melt curve consisted of $95^{\circ} \mathrm{C}$ for $1 \mathrm{~min}, 55^{\circ} \mathrm{C}$ for $1 \mathrm{~min}$, seventy-one cycles of $60.5^{\circ} \mathrm{C}$ for $30 \mathrm{~s}$ increasing the temperature with each repeat. The melt curve was evaluated for a single fluorescent peak per PCR reaction; multiple fluorescent peaks indicate non-specific primer amplification (i.e. primer dimer formation).

Abundance of R. flavefaciens and F. succinogenes was determined using TaqMan ${ }^{B}$ primers and probes (Table 2) as previously designed by Hastie et $a l^{(44)}$. Each $20 \mu$ l reaction contained $65 \mathrm{ng}$ DNA, $10 \mu \mathrm{l}$ HotStart-IT Probe qPCR Master Mix 2x (no. 75770; USB Corp.), $1 \mu \mathrm{l}$ of 20X TaqMan $^{\circledR}$ assay (AB TaqMan ${ }^{\circledR}$ Assay; Table 2), $0.4 \mu \mathrm{l}$ of ROX $^{\mathrm{TM}}$ as passive reference dye (no. 75768; USB Corp.) and $7.6 \mu \mathrm{l}$ nanopure nuclease-free water (no. E476; Ameresco Inc.). PCR conditions consisted of one cycle of 2 min at $95^{\circ} \mathrm{C}$ for activation of HotStart-IT polymerase, followed by thirty-five cycles of denaturation at $95^{\circ} \mathrm{C}$ for $15 \mathrm{~s}$, primer annealing and real-time detection at $60^{\circ} \mathrm{C}$ for $30 \mathrm{~s}$, and extension at $72^{\circ} \mathrm{C}$ for 1 min carried out with a 7300 realtime PCR detection system (Applied Biosystems). Standard curves were constructed using 6-fold dilutions of target DNA from pure cultures of R. flavefaciens $\mathrm{S} 85$ and F. succinogenes FD-1 provided by Dr Roderick Mackie (University of Illinois, Urbana). Absolute abundance was calculated as $\log _{10}$ copies $/ g$ faeces. The abundance of active F. succinogenes and R. flavefaciens was determined as described above except that $70 \mathrm{ng}$ RNA were used as the starting material and converted to complementary DNA by the addition of $0 \cdot 2 \mu \mathrm{l}$ Moloney murine leukemia virus (M-MLV) RT (no. 75783; USB Corp.) and $0.2 \mu \mathrm{l}$ RNase inhibitor (no. 75782; USB Corp.). PCR conditions as described above were preceded by one cycle of $5 \mathrm{~min}$ at $50^{\circ}$ C for reverse transcription of RNA before amplification. Negative controls, without complementary DNA and reverse transcriptase, were run to rule out DNA contamination. Each reaction was prepared and carried out in biological and technical duplicates as described ${ }^{(66)}$ using an ABI 7300 (Applied Biosystems).

\section{Statistical analysis}

Duplicate digestibility, plasma and faecal VFA, and bacterial abundance analyses were conducted on samples pooled within horse for the collection period. Data were analysed using SAS (version 9.2; SAS Institute Inc.). A GLIMMIX procedure was used for analysis, with mare within group as the subject, using the following model for analysis:

$$
\mathrm{Y}_{\mathrm{ij}}=\mu+\mathrm{G}_{\mathrm{i}}+\mathrm{E}_{(\mathrm{i}) \mathrm{j}}
$$

where $\mathrm{Y}_{\mathrm{ij}}=$ dependent variables DMD, NDFD, ADFD, plasma acetate, faecal acetate, propionate and butyrate, and abundance of total bacteria, Firmicutes, Bacteroidetes, F. succinogenes and $R$. flavefaciens; $\mu=$ the mean of $Y ; G_{i}=$ fixed effect of group (overweight and moderate condition); and $\mathrm{E}_{(\mathrm{i}) \mathrm{j}}=$ random effect of mare within group. For each model, residual plots were inspected to verify the assumption that errors followed a normal distribution with a constant variance. Differences between groups were considered significant with $P<0 \cdot 05$. Data are presented as mean values with their standard errors.

\section{Results}

\section{Animals and apparent digestibility}

Body weight, BCS, rump fat thickness and DMI for the two groups are presented in Table 3. Body weight $(P=0.35)$ did not differ between groups; however, BCS was higher $(P<$ $0.01)$ and mean rump fat was larger $(P=0.03)$ in overweight mares. DMI did not differ between groups $(P=0.61)$. DM, NDF and ADF apparent digestibilities did not differ between groups (Table 4).

\section{Volatile fatty acids}

Faecal acetate, propionate and butyrate concentrations did not differ significantly between overweight and moderatecondition mares (Table 5). However, mean plasma acetate concentration was higher $(P=0.034)$ in the overweight mares $(1.55($ SEM $0 \cdot 10) \mathrm{mmol} / \mathrm{l})$ than the moderate-condition mares $(1 \cdot 39(\operatorname{SEM} 0 \cdot 11) \mathrm{mmol} / \mathrm{l})$.

Table 3. Mare body weight (BW), body condition score (BCS) and rump fat thickness measured on days 0 and 15 and DM intake (DMI) during days 11-14 (Mean values with their standard errors)

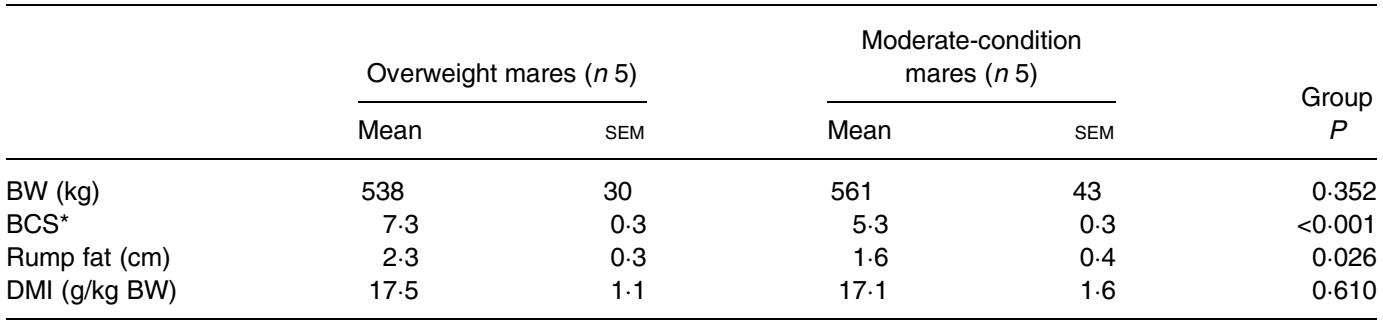

* BCS measured on a scale of 1 to 9 . 
Table 4. Hay digestibility in overweight and moderate-condition mares during days 11-14 of the study (Mean values with their standard errors)

\begin{tabular}{|c|c|c|c|c|c|}
\hline & \multicolumn{2}{|c|}{ Overweight mares ( $n 5$ ) } & \multicolumn{2}{|c|}{ Moderate-condition mares $(n 5)$} & \multirow{2}{*}{$\begin{array}{c}\text { Group } \\
\quad P\end{array}$} \\
\hline & Mean & SEM & Mean & SEM & \\
\hline Digestible energy & & & & & 0.37 \\
\hline MJ/kg DM & 9.42 & 0.59 & $9 \cdot 13$ & 0.34 & \\
\hline Mcal/kg DM & $2 \cdot 25$ & 0.14 & $2 \cdot 18$ & 0.08 & \\
\hline \multicolumn{6}{|c|}{ Digestibility (g/100 g) } \\
\hline DM & 0.56 & 0.03 & 0.54 & 0.02 & 0.191 \\
\hline OM & 0.58 & 0.00 & 0.56 & 0.02 & 0.189 \\
\hline NDF & 0.60 & 0.03 & 0.59 & 0.03 & 0.506 \\
\hline ADF & 0.55 & 0.03 & 0.54 & 0.03 & 0.514 \\
\hline
\end{tabular}

OM, organic matter; NDF, neutral-detergent fibre; ADF, acid-detergent fibre.

Table 5. Volatile fatty acid concentrations in the faeces ( $\mathrm{mg} / \mathrm{g}$ dry faeces) and plasma (mmol/l) of overweight and moderate-condition mares on days $11-14$ of the study

(Mean values with their standard errors)

\begin{tabular}{|c|c|c|c|c|c|}
\hline & \multicolumn{2}{|c|}{ Overweight mares ( $n 5$ ) } & \multicolumn{2}{|c|}{ Moderate-condition mares $(n 5)$} & \multirow{2}{*}{$\begin{array}{c}\text { Group } \\
\quad P\end{array}$} \\
\hline & Mean & SEM & Mean & SEM & \\
\hline \multicolumn{6}{|l|}{ Faeces } \\
\hline Acetate & 8.28 & 1.76 & $8 \cdot 31$ & 1.40 & 0.973 \\
\hline Propionate & 4.44 & 1.35 & 4.70 & 1.33 & 0.770 \\
\hline Butyrate & 0.68 & 0.17 & 0.68 & 0.19 & 0.972 \\
\hline \multicolumn{6}{|l|}{ Plasma } \\
\hline Acetate & 1.55 & 0.10 & 1.39 & 0.11 & 0.034 \\
\hline
\end{tabular}

\section{Faecal bacterial abundance}

The abundance of total bacterial 16S rRNA copies, as determined using TaqMan ${ }^{\circledR}$ primers/probes, was higher $(P<$ 0.001) than with SYBR ${ }^{\circledR}$ Green primers (Table 6). There was no statistically significant difference in the abundance of total bacteria, Firmicutes and Bacteroidetes $16 \mathrm{~S}$ rDNA, as determined using SYBR ${ }^{\circledR}$ Green primers, from the faeces of overweight $v$. moderate-condition mares (Table 6). A difference in the average Firmicutes:Bacteroidetes ratio in the overweight (2.76 (SEM 0.46)) and moderate-condition (3.09 (SEM $0 \cdot 35)$ ) mares was not detected $(P=0 \cdot 588)$. Differences in total bacteria, $R$. flavefaciens or $F$. succinogenes $16 \mathrm{~S} \mathrm{rDNA}$ and $16 \mathrm{~S}$ rRNA abundance, as determined using TaqMan ${ }^{\circledR}$ primers/probes, were not detected between overweight $v$.

Table 6. Abundance ( $\log _{10}$ copies $16 \mathrm{~S}$ ribosomal DNA (rDNA) and $16 \mathrm{~S}$ ribosomal RNA (rRNA)/g faeces) and 16S rDNA:16S rRNA ratios for total bacteria, Firmicutes, Bacteroidetes, Ruminococcus flavefaciens and Fibrobacter succinogenes (Mean values with their standard errors)

\begin{tabular}{|c|c|c|c|c|c|}
\hline & \multicolumn{2}{|c|}{ Overweight mares } & \multicolumn{2}{|c|}{ Moderate-condition mares } & \multirow{2}{*}{$\begin{array}{c}\text { Group } \\
\quad P\end{array}$} \\
\hline & Mean & SEM & Mean & SEM & \\
\hline \multicolumn{6}{|c|}{$\log _{10}$ copies $16 \mathrm{~S}$ rDNA/g faeces } \\
\hline Total bacteria† & 9.07 & 0.08 & $9 \cdot 14$ & 0.06 & 0.505 \\
\hline Total bacteriał & $8 \cdot 38$ & 0.03 & $8 \cdot 38$ & 0.02 & 0.824 \\
\hline Firmicutes† & 8.89 & 0.08 & 9.07 & 0.08 & 0.125 \\
\hline Bacteroidetes $\dagger$ & 8.48 & 0.07 & 8.60 & 0.04 & 0.180 \\
\hline R. flavefaciens $\ddagger$ & $6 \cdot 77$ & 0.09 & $6 \cdot 82$ & 0.05 & 0.643 \\
\hline F. succinogenesł & $5 \cdot 32$ & 0.11 & 5.54 & 0.06 & 0.142 \\
\hline \multicolumn{6}{|c|}{$\log _{10}$ copies $16 \mathrm{~S}$ rRNA /g faeces $\ddagger$} \\
\hline Total bacteria & 6.88 & 0.06 & 7.05 & 0.09 & 0.152 \\
\hline R. flavefaciens & $5 \cdot 13$ & 0.05 & 5.35 & 0.12 & 0.131 \\
\hline F. succinogenes & 4.96 & 0.20 & 4.97 & 0.16 & 0.956 \\
\hline \multicolumn{6}{|c|}{ 16S rRNA:16S rDNA ratioł } \\
\hline Total bacteria & 0.82 & 0.01 & 0.84 & 0.01 & 0.158 \\
\hline R. flavefaciens & 0.76 & 0.01 & 0.78 & 0.01 & 0.156 \\
\hline F. succinogenes & $0.93^{*}$ & 0.04 & $0.90^{*}$ & 0.02 & 0.421 \\
\hline
\end{tabular}

* Mean value of 16S rRNA:16S rDNA ratio was significantly different from that for $R$. flavefaciens $(P<0.001)$.

† Bacterial abundance was determined by the use of SYBR ${ }^{\circledR}$ Green primers (see Table 2).

$\ddagger$ Bacterial abundance was determined by the use of TaqMan ${ }^{\circledR}$ primers/probes (see Table 2 ). 
moderate-condition mares (Table 6). The 16S rRNA:16S rDNA ratio was higher $(P<0 \cdot 001)$ for $F$. succinogenes than for all bacteria and R. flavafaciens in both groups (Table 6).

\section{Discussion}

\section{Animals and apparent digestibility}

The mares in the present study were chosen because they had been under the same management and feeding practices for the past 3 or more years before the study yet displayed variable body-condition phenotypes. No differences in DM or fibre digestibilities were detected between overweight and moderatecondition mares in the present study despite all fractions being numerically higher in the overweight mares. A difference in the mean hay DE between overweight and moderate-condition mares of $251 \mathrm{~kJ} / \mathrm{kg}$ hay DM $(0.06 \mathrm{Mcal} / \mathrm{kg}$ hay DM) translates to an additional $1025 \mathrm{MJ} \mathrm{DE} \mathrm{(245} \mathrm{Mcal} \mathrm{DE)/year} \mathrm{in} \mathrm{a}$ $500 \mathrm{~kg}$ overweight mare fed $20 \mathrm{~g} / \mathrm{kg}$ BW per d hay, DM basis or $10 \mathrm{~kg} \mathrm{DM}$ per $\mathrm{d}$. The additional energy could conceivably be stored as fat. Generally speaking, a $32.2 \mathrm{MJ}(7 \cdot 70$ Mcal) energy surplus/deficit is needed to gain/lose $1 \mathrm{~kg}$ body weight ${ }^{(67)}$. This estimate does not take into account differences between fat and lean tissue gained/lost during weight gain/loss; however, the 1026 MJ DE (245 Mcal DE)/year could hypothetically lead to an increase of $32 \mathrm{~kg}$ body weight in 1 year's time.

Ragnarsson \& Jansson ${ }^{(59)}$ reported a 0.03 difference in haylage digestibility between six Standardbred and six Icelandic horses $(0.57 v .0 .54)$. Increased individual variation in digestibility was anticipated in the present study, as compared with the Ragnarsson study, due to breed variation. Furthermore, the facilities in the present study allowed for a maximum of ten horses to be evaluated during the same period to avoid the effect of time/period. We used a $10 \mathrm{~d}$ adaptation period and $4 \mathrm{~d}$ collection period as this is a standard approach in equine digestibility trials ${ }^{(60)}$. We do not anticipate that provision of a longer adaptation period would have allowed us to detect a difference in digestibility. However, based on the variation in the present study, we would need a larger cohort of obese $(n 14)$ and lean $(n 14)$ adult mares to detect a 0.02 difference in grass hay DM digestibility.

The overweight mares may, if allowed ad libitum access, consume more total daily DM than the moderate-condition mares, thereby influencing total daily energy intake. We did not evaluate voluntary OG hay consumption in the overweight $v$. moderate-condition mares and thus are unable to comment on the effect of voluntary intake on the overweight condition. Conversely, we cannot comment on the potential effect of voluntary overconsumption on digestibility.

\section{Volatile fatty acids}

Faecal VFA concentrations in the present study (Table 5) were higher than concentrations in the faeces of geldings limit-fed lucerne cubes $(2.84 \mathrm{mg}$ acetate, $0.89 \mathrm{mg}$ propionate and $0.55 \mathrm{mg}$ butyrate $/ \mathrm{g}$ faecal DM) as reported by Hussein et $a l^{(17)}$. This difference could be due to an effect of diet (lucerne $v$. hay) or individual variation in VFA production by hindgut microbes or VFA absorption. Argenzio et al. ${ }^{(15)}$ reported that total VFA concentrations varied from 20 to $60 \mathrm{mmol} / \mathrm{l}$ in the hindgut among ponies fed the same pelleted feed. Other VFA, such as valerate, isovalerate and isobutyrate, were not evaluated in the present study as they collectively represent less than $10 \%$ of total VFA in horse faeces ${ }^{(17)}$. Therefore, a comparison of the VFA ratios in the present study and prior studies cannot be made.

Plasma acetate concentrations in the present study were higher $(>1.0 \mathrm{mmol} / \mathrm{l}$; Table 5) than previously reported in horses $(0.56(\text { SEM } 0.07) \mathrm{mmol} / \mathrm{l})^{(68)}$ and human subjects $(<0.1 \mathrm{mmol} / \mathrm{l})^{(69)}$. The adult Standardbreds in the Waller et al. study ${ }^{(68)}$ were managed on a sweet feed and forage diet $v$. forage-only diet in the present study. The exact cause and significance of higher plasma acetate in the overweight $v$. moderate-condition mares were beyond the scope of the study. Possible causes for increased plasma acetate in overweight mares could be due to increased microbial VFA production, reduced microbial acetate utilisation/ metabolism ${ }^{(70,71)}$, increased VFA absorption across the gut mucosa, reduced acetate oxidation, increased hepatic acetate production $^{(72,73)}$ or reduced hepatic TAG synthesis. VFA absorption is negatively correlated with gut lumen $\mathrm{pH}$ and positively associated with the concentration of a given VFA in the lumen ${ }^{(12)}$. Diet influences hindgut and faecal lumen $\mathrm{pH}$, with non-structural carbohydrates (mono/disaccharides, starches, fructans), as found in grains, favouring a more acidic $\mathrm{pH}^{(18,41,74,75)}$. Reductions in hindgut $\mathrm{pH}$ may lead to enhanced VFA absorption secondarily due to mucosal barrier compromise, which could lead to the horse's demise ${ }^{(76,77)}$. Mares in the present study were fed a grass-hay diet low in non-structural carbohydrates $^{(33)}$ with no inclusion of grains. Cani \& Delzenne ${ }^{(78)}$ described a cascading process of obesity, altered gut microbes, altered gut barrier function, metabolic endotoxaemia and subsequent inflammation in human models. We did not evaluate the entire microbial population in the present study; however, we did not find evidence of altered gut microbes between overweight and moderate-condition mares.

The potential effects of increased plasma acetate in overweight horses are numerous. Of the VFA, peripheral tissues directly utilise acetate as an energy source ${ }^{(27)}$. Once in the blood, acetate may be aerobically oxidised and directly used for energy ${ }^{(27)}$ or stored as TAG in adipose and skeletal tissue ${ }^{(28)}$. Once absorbed, acetate can be oxidised via the tricarboxylic acid (TCA) cycle or stored in the form of adipose, as acetate is the primary substrate for de novo fat synthesis in the horse ${ }^{(28)}$. Furthermore, acetate may directly increase hepatic lipogenesis, lipoprotein lipase and subsequent fat storage as found in the murine model ${ }^{(78)}$. In humans, acetate is used as a substrate for de novo fatty acid synthesis in adipose tissue ${ }^{(79)}$ and VFA are recognised as a link between obesity and gut microbes in human subjects ${ }^{(80)}$. Therefore, the cause and significance of higher plasma acetate in overweight $v$. moderatecondition mares should be further explored. VFA may secondarily influence energy intake by influencing food intake. In ruminants, rumen infusions of acetate decrease intake ${ }^{(81,82)}$. Similarly, rectal acetate infusion increased plasma peptide YY, 
which generally inhibits food intake, in human subjects ${ }^{(69)}$. To our knowledge the effects of parenteral or rectal acetate infusions have not been evaluated in horses; we feel that this would be worth investigating. Furthermore, as previously discussed, we did not evaluate voluntary intake in the present study and thus cannot evaluate a potential relationship between plasma acetate and intake.

Faecal VFA concentrations do not accurately reflect those in the caecum and colon ${ }^{(15)}$. Therefore, without a direct measurement of caecal/colon VFA concentrations, we cannot speculate whether a difference in caecal/colon VFA concentrations would be detected in this cohort. Similarly, plasma VFA concentrations in the jugular vein will not accurately represent microbial VFA production or even portal vein VFA concentrations, particularly for propionate and butyrate. Most absorbed propionate is converted into glucose by the liver and provides 50-61\% of blood glucose in horses ${ }^{(83)}$, and butyrate is the preferred energy substrate for colonocytes and thus plays an important role in the maintenance of hindgut health. Therefore, of the venous VFA, we focused on plasma acetate. Measurement of portal venous VFA concentration in conjunction with caecal and colon VFA concentrations would be a more accurate method to elucidate VFA absorption rates in vivo and thus determine if a difference in VFA absorption exists between overweight and moderate-condition horses. Portal vein catheterisation in horses has been described ${ }^{(84)}$ and can be placed in conjunction with caecal cannulas; however, both are invasive procedures.

\section{Faecal bacterial abundance}

The relative abundance of Firmicutes in the hindgut is positively associated with obesity in human subjects ${ }^{(21,36)}$, pigs ${ }^{(34)}$ and rodents ${ }^{(20,35)}$. However, a difference in abundance of Firmicutes was not detected between overweight and moderate-condition adult mares in the present study (Table 6). Furthermore, the faecal Firmicutes:Bacteroidetes ratio in the faeces of overweight $v$. moderate-condition mares did not differ. We hypothesise that $R$. favafaciens and F. succinogenes $16 \mathrm{~S}$ rRNA abundance would be higher in the overweight $v$. moderate-condition mares as an indication of higher fibrolytic bacterial activity. However, we did not detect a difference in the abundance of $R$. favafaciens and F. succinogenes in overweight $v$. moderate-condition mares.

The higher 16S rRNA:16S rDNA ratio for F. succinogenes may represent a higher activity of $F$. succinogenes in the rectum of adult mares fed grass hay as compared with R. flavafaciens. F. succinogenes plays an important fibrolytic role in herbivores fed a grass-based diet ${ }^{(85)}$. F. succinogenes has superior fibrolytic activity as compared with Ruminococcus spp. ${ }^{(86,87)}$, which may explain the increased 16S rRNA:16S rDNA ratio, a representation of activity. Furthermore, time of day, with respect to feeding, influences the abundance of $F$. succinogenes in the rumen of dairy cattle ${ }^{(88)}$. However, the effect of time or feeding was not evaluated in the present study, as faecal samples for microbial analysis were collected once daily, before the morning feeding.
The higher abundance of total bacteria as determined using SYBR ${ }^{\circledR}$ Green primers $v$. TaqMan ${ }^{\circledR}$ primers/probes (Table 6) is probably due to the higher specificity when using TaqMan ${ }^{\circledR}$ primer/probe combinations ${ }^{(89)}$. TaqMan $\left.^{(}\right)$probes bind only between the two PCR primers; therefore, the complimentary sequence must be present for the primers to bind and subsequently the probe to bind and result in a fluorescent signal and thus TaqMan ${ }^{\circledR}$ probes are indicated when evaluating bacterial members in low abundance within a population ${ }^{(90)}$. In contrast, SYBR ${ }^{\circledR}$ Green binds and fluoresces with any doublestranded DNA; SYBR ${ }^{\circledR}$ Green primers are less expensive than TaqMan ${ }^{\circledR}$ probes, can be used with a wider range of primers, and are commonly used when evaluating bacterial members in high abundance within a population ${ }^{(90)}$.

This is the first study, to the authors' knowledge, of evaluating $16 \mathrm{~S}$ rDNA abundance alongside $16 \mathrm{~S}$ rRNA abundance to characterise the equine faecal bacterial population with an emphasis on fibrolytic bacteria. Evaluation of $16 \mathrm{~S}$ rDNA abundance has been used to evaluate the abundance of bacteria in equine gut/faecal samples ${ }^{(44)}$, but does not distinguish between viable and non-viable bacteria. The 16S rRNA abundance and can be used as an indicator of bacterial activity ${ }^{(91)}$ and is typically higher than $16 \mathrm{~S} \mathrm{rDNA}$ abundance in pure culture ${ }^{(91,92)}$. As reported in the present study, we expected the $16 \mathrm{~S}$ rRNA abundance to be lower than the $16 \mathrm{~S}$ rDNA abundance in faeces because RNA is a less stable molecule than DNA. Furthermore, both viable and non-viable bacteria are present in faeces of adult mares and the latter would not be transcribing the rDNA into rRNA. We used faecal samples as a non-invasive means to evaluate two different groups of horses; however, we cannot directly infer that the findings presented here represent the caecal and colonic microbiome.

In conclusion, overweight mares have higher plasma acetate concentrations than lean mares fed the same commercially available OG hay diet. The cause and significance of this finding should be further explored as a mechanism linking obesity and gut microbes.

\section{Acknowledgements}

Funding was provided by a Virginia-Maryland College of Veterinary Medicine Intramural Grant. The commercially available OG hay was donated by Standlee Hay Company. The authors would like to thank Dr Roderick Mackie, University of Illinois, for supplying the F. succinogenes and R. Alavafaciens strains that served as standards for real-time PCR analysis, Dr Amy Tanner and Barbara Self for their assistance in the digestibility analyses, Dr Mark Hanigan, Tara Wiles and Deepthi Nayananjalie for their assistance in VFA analysis, and Dr Mike McGilliard for statistical guidance. We would like to give special thanks to the twenty-six undergraduate student volunteers that assisted with horse care, sample collection, sample processing and analysis.

M. L. S. authored the paper, established the study design, carried our animal care, sample collection and analysis. M. A. P. and A. O. B. were co-authors on this paper, co-advised the lead author in study design, and provided editorial comments. S. C. M. helped with horse 
acquisition and care along with sample collection and analysis. W. S. S. was a co-author on this paper, principal investigator for the grant supporting the research, contributed editorial comments, and advised the lead author from study design to manuscript. The authors declare no conflict of interest.

\section{References}

1. Thatcher CD, Pleasant RS, Geor RJ, et al. (2012) Prevalence of overconditioning in mature horses in Southwest Virginia during the summer. J Vet Intern Med 26, 1413-1418.

2. Wyse CA, Mcnie KA, Tannahill VJ, et al. (2008) Prevalence of obesity in riding horses in Scotland. Vet Rec 162, 590.

3. Stephenson HM, Green MJ \& Freeman SL (2011) Prevalence of obesity in a population of horses in the UK. Vet Rec 168, 131-131.

4. Sessions D, Reedy S, Vick M, et al. (2004) Development of a model for inducing transient insulin resistance in the mare: preliminary implications regarding the estrous cycle. J Anim Sci 82, 2321-2328.

5. Vick M, Sessions D, Murphy B, et al. (2006) Obesity is associated with altered metabolic and reproductive activity in the mare: effects of metformin on insulin sensitivity and reproductive cyclicity. Reprod Fertil Dev 18, 609-617.

6. Sillence M, Noble G \& McGowan C (2006) Fast food and fat fillies: the ills of western civilisation. Vet J 172, 396-397.

7. Hoffman RM, Boston RC, Stefanovski D, et al. (2003) Obesity and diet affect glucose dynamics and insulin sensitivity in thoroughbred geldings. J Anim Sci 81, 2333-2342.

8. Frank N, Elliott S, Brandt L, et al. (2006) Physical characteristics, blood hormone concentrations, and plasma lipid concentrations in obese horses with insulin resistance. J Am Vet Med Assoc 228, 1383-1390.

9. Vick M, Adams A, Murphy B, et al. (2007) Relationships among inflammatory cytokines, obesity, and insulin sensitivity in the horse. J Anim Sci 85, 1144-1155.

10. Treiber K, Kronfeld D \& Geor R (2006) Insulin resistance in equids: possible role in laminitis. J Nutr 136, 2094S-2098S.

11. Treiber K, Kronfeld D, Hess T, et al. (2006) Evaluation of genetic and metabolic predispositions and nutritional risk factors for pasture-associated laminitis in ponies. J Am Vet Med Assoc 228, 1538-1545.

12. Bergman EN (1990) Energy contributions of volatile fatty-acids from the gastrointestinal-tract in various species. Physiol Rev 70, $567-590$.

13. Elsden SR, Hitchcock MWS, Marshall RA, et al. (1946) Volatile acid in the digesta of ruminants and other animals. J Exp Biol 22, 191202.

14. Hintz HF, Argenzio RA \& Schryver HF (1971) Digestion coefficients, blood glucose levels and molar percentage of volatile acids in intestinal fluid of ponies fed varying forage-grain ratios. J Anim Sci 33, 992-995.

15. Argenzio RA, Southworth M \& Stevens CE (1974) Sites of organic acid production and absorption in the equine gastrointestinal tract. Am J Physiol 226, 1043-1050.

16. Glinsky MJ, Smith RM, Spires HR, et al. (1976) Measurement of volatile fatty-acid production-rates in cecum of pony. Anim Sci 42, 1465-1470.

17. Hussein HS, Vogedes LA, Fernandez GCJ, et al. (2004) Effects of cereal grain supplementation on apparent digestibility of nutrients and concentrations of fermentation end-products in the feces and serum of horses consuming alfalfa cubes. J Anim Sci 82, 1986-1996.

18. Swyers KL, Burk AO, Hartsock TG, et al. (2008) Effects of direct-fed microbial supplementation on digestibility and fermentation end-products in horses fed low- and high-starch concentrates. J Anim Sci 86, 2596-2608.

19. Julliand V, de Fombelle A, Drogoul C, et al. (2001) Feeding and microbial disorders in horses: Part 3 - Effects of three hay:grain ratios on microbial profile and activities. J Equine Vet Sci 21, 543546.

20. Ley R, Bäckhed F, Turnbaugh P, et al. (2005) Obesity alters gut microbial ecology. Proc Natl Acad Sci U S A 102, 11070-11075.

21. Ley R, Turnbaugh P, Klein S, et al. (2006) Microbial ecology: human gut microbes associated with obesity. Nature 444, 1022-1023.

22. Bäckhed F, Ding H, Wang T, et al. (2004) The gut microbiota as an environmental factor that regulates fat storage. Proc Natl Acad Sci U S A 101, 15718-15723.

23. Fleissner CK, Huebel N, Abd El-Bary MM, et al. (2010) Absence of intestinal microbiota does not protect mice from diet-induced obesity. Br J Nutr 104, 919-929.

24. Turnbaugh P, Ley R, Mahowald M, et al. (2006) An obesity-associated gut microbiome with increased capacity for energy harvest. Nature 444, 1027-1031.

25. Roelofsen H, Priebe MG \& Vonk RJ (2010) The interaction of short-chain fatty acids with adipose tissue: relevance for prevention of type 2 diabetes. Benef Microbes 1, 433-437.

26. Arora T, Sharma R \& Frost G (2011) Propionate. Anti-obesity and satiety enhancing factor? Appetite 56, 511-515.

27. Pethick DW, Rose RJ, Bryden WL, et al. (1993) Nutrient utilisation by the hindlimb of thoroughbred horses at rest. Equine Vet J 25, $41-44$.

28. Suagee JK, Corl BA, Crisman MV, et al. (2010) De novo fatty acid synthesis and NADPH generation in equine adipose and liver tissue. Comp Biochem Physiol B Biochem Mol Biol 155, 322-326.

29. Daly K, Stewart CS, Flint H, et al. (2001) Bacterial diversity within the equine large intestine as revealed by molecular analysis of cloned 16S rRNA genes. FEMS Microbiol Ecol 38, 141-151.

30. Shepherd ML, Swecker WS Jr, Jensen RV, et al. (2012) Characterization of the fecal bacteria communities of forage-fed horses by pyrosequencing of $16 \mathrm{~S}$ rRNA V4 gene amplicons. FEMS Microbiol Lett 326, 62-68.

31. Willing B, Voros A, Roos S, et al. (2009) Changes in faecal bacteria associated with concentrate and forage-only diets fed to horses in training. Equine Vet J 41, 908-914.

32. Daly K, Proudman CJ, Duncan SH, et al. (2012) Alterations in microbiota and fermentation products in equine large intestine in response to dietary variation and intestinal disease. Br J Nutr 107, 989-995.

33. Shepherd ML, Pleasant RS, Crisman MV, et al. (2012) Effects of high and moderate non-structural carbohydrate hay on insulin, glucose, triglyceride, and leptin concentrations in overweight Arabian geldings. J Anim Physiol Anim Nutr (Berl) 96, 428-435.

34. Guo X, Xia X, Tang R, et al. (2008) Development of a real-time PCR method for Firmicutes and Bacteroidetes in faeces and its application to quantify intestinal population of obese and lean pigs. Lett Appl Microbiol 47, 367-373.

35. Turnbaugh PJ, Baeckhed F, Fulton L, et al. (2008) Diet-induced obesity is linked to marked but reversible alterations in the mouse distal gut microbiome. Cell Host Microbe 3, 213-223.

36. Turnbaugh P, Hamady M, Yatsunenko T, et al. (2009) A core gut microbiome in obese and lean twins. Nature 457, 480-484.

37. Ji YS, Kim HN, Park HJ, et al. (2012) Modulation of the murine microbiome with a concomitant anti-obesity effect by Lactobacillus rbamnosus GG and Lactobacillus sakei NR28. Benef Microbes 3, 13-22.

38. Pedersen R, Andersen AD, Molbak L, et al. (2013) Changes in the gut microbiota of cloned and non-cloned control pigs during development of obesity: gut microbiota during development of obesity in cloned pigs. BMC Microbiol 13, 30.

39. Mujico JR, Baccan GC, Gheorghe A, et al. (2013) Changes in gut microbiota due to supplemented fatty acids in diet-induced obese mice. Br J Nutr 110, 711-720.

40. Verdam FJ, Fuentes S, de Jonge C, et al. (2013) Human intestinal microbiota composition is associated with local and systemic inflammation in obesity. Obesity (Silver Spring) 21, E607-E615.

41. Garner H, Coffman J, Hahn A, et al. (1975) Equine laminitis of alimentary origin: an experimental model. Am J Vet Res 36, $441-444$. 
42. Mackie RI \& Wilkins CA (1988) Enumeration of anaerobic bacterial microflora of the equine gastrointestinal tract. Appl Environ Microbiol 54, 2155-2160.

43. Lin CZ \& Stahl DA (1995) Taxon-specific probes for the cellulolytic genus Fibrobacter reveal abundant and novel equine-associated populations. Appl Environ Microbiol 61, 1348-1351.

44. Hastie PM, Mitchell K \& Murray JA (2008) Semi-quantitative analysis of Ruminococcus flavefaciens, Fibrobacter succinogenes and Streptococcus bovis in the equine large intestine using real-time polymerase chain reaction. Br J Nutr 100, 561-568.

45. Gibson G \& Roberfroid M (1995) Dietary modulation of the human colonic microbiota: introducing the concept of prebiotics. J Nutr 125, 1401-1412.

46. Daly K \& Shirazi-Beechey S (2003) Design and evaluation of group-specific oligonucleotide probes for quantitative analysis of intestinal ecosystems: their application to assessment of equine colonic microflora. FEMS Microbiol Ecol 44, 243-2525.

47. Julliand V, de Vaux A, Millet L, et al. (1999) Identification of Ruminococcus flavefaciens as the predominant cellulolytic bacterial species of the equine cecum. Appl Environ Microbiol 65, 3738-3741.

48. Buff P, Dodds A, Morrison C et al. (2002) Leptin in horses: tissue localization and relationship between peripheral concentrations of leptin and body condition. J Anim Sci 80, 2942-2948.

49. Thatcher C, Pleasant R, Geor R et al. (2008) Prevalence of obesity in mature horses: an equine body condition study. I Anim Physiol Anim Nutr 92, 222.

50. Vermorel M, Vernet J \& Martin-Rosset W (1997) Digestive and energy utilisation of two diets by ponies and horses. Livest Prod Sci 51, 13-19.

51. Cummings JH (1981) Short chain fatty acids in the human colon. Gut 22, 763-779.

52. McNeil N (1984) The contribution of the large intestine to energy supplies in man. Am J Clin Nutr 39, 338-342.

53. Titus E \& Ahearn GA (1992) Vertebrate gastrointestinal fermentation: transport mechanisms for volatile fatty acids. Am J Physiol 262, R547-R553.

54. von Engelhardt W, Bartels J, Kirschberger S, et al. (1998) Role of short-chain fatty acids in the hind gut. Vet $Q$ 20, S52-S59.

55. Xu J \& Gordon JI (2003) Inaugural article: honor thy symbionts. Proc Natl Acad Sci U S A 100, 10452-10459.

56. Bera-Maillet C, Ribot Y \& Forano E (2004) Fiber-degrading systems of different strains of the genus Fibrobacter. Appl Environ Microbiol 70, 2172-2179.

57. Henneke DR, Potter GD, Kreider JL, et al. (1983) Relationship between condition score, physical measurements and body-fat percentage in mares. Equine Vet J 15, 371-372.

58. National Research Council (2007) Nutrient Requirements of Horses, 6th ed. Washington, DC: National Academies Press.

59. Ragnarsson S \& Jansson A (2011) Comparison of grass haylage digestibility and metabolic plasma profile in Icelandic and Standardbred horses. J Anim Physiol Anim Nutr 95, 273-279.

60. Eckert JV, Myer RO, Warren LK, et al. (2010) Digestibility and nutrient retention of perennial peanut and bermudagrass hays for mature horses. J Anim Sci 88, 2055-2061.

61. Westervelt R, Stouffer J, Hintz H, et al. (1976) Estimating fatness in horses and ponies. I Anim Sci 43, 781-785.

62. AOAC (2000) Official Methods of Analysis. Washington, DC: Association of Official Analytical Chemists.

63. Staniar WB, Bussard JR, Repard NM, et al. (2010) Voluntary intake and digestibility of teff hay fed to horses. J Anim Sci 88, 3296-3303.

64. Otto ER, Yokoyama M, Hengemuehle S, et al. (2003) Ammonia, volatile fatty acids, phenolics, and odor offensiveness in manure from growing pigs fed diets reduced in protein concentration. J Anim Sci 81, 1754-1763.

65. Kristensen NB (2000) Quantification of whole blood short-chain fatty acids by gas chromatographic determination of plasma 2-chloroethyl derivatives and correction for dilution space in erythrocytes. Acta Agr Scand A-An 50, 231-236.
66. Price KL, Totty HR, Lee HB et al. (2010) Use of Saccharomyces cerevisiae fermentation product on growth performance and microbiota of weaned pigs during Salmonella infection. J Anim Sci 88, 38963908.

67. Hall KD (2008) What is the energy deficit required per unit weight loss? Int J Obes 32, S99-S99.

68. Waller AP, Geor RJ, Spriet LL, et al. (2009) Oral acetate supplementation after prolonged moderate intensity exercise enhances early muscle glycogen resynthesis in horses. Exp Physiol 94, 888898.

69. Freeland KR \& Wolever TM (2010) Acute effects of intravenous and rectal acetate on glucagon-like peptide-1, peptide YY, ghrelin, adiponectin and tumour necrosis factor- $\alpha$. BrJ Nutr 103, 460-466.

70. Duncan S, Barcenilla A, Stewart C, et al. (2002) Acetate utilization and butyryl coenzyme A $(\mathrm{CoA})$ : acetate-CoA transferase in butyrate-producing bacteria from the human large intestine. Appl Environ Microbiol 68, 5186-5190.

71. Duncan SH, Holtrop G, Lobley GE, et al. (2004) Contribution of acetate to butyrate formation by human faecal bacteria. $\mathrm{Br} J$ Nutr 91, 915-923.

72. Siler SQ, Neese RA \& Hellerstein MK (1999) De novo lipogenesis, lipid kinetics, and whole-body lipid balances in humans after acute alcohol consumption. Am J Clin Nutr 70, 928-936.

73. Yamashita H, Kaneyuki T \& Tagawa K (2001) Production of acetate in the liver and its utilization in peripheral tissues. Biochim Biophys Acta 1532, 79-87.

74. Garner HE, Hutcheson DP, Coffman JR, et al. (1977) Lactic acidosis: a factor associated with equine laminitis. J Anim Sci 45, 10371041.

75. van Eps A \& Pollitt C (2006) Equine laminitis induced with oligofructose. Equine Vet J 38, 203-208.

76. Mungall B, Kyaw-Tanner M \& Pollitt C (2001) In vitro evidence for a bacterial pathogenesis of equine laminitis. Vet Microbiol 79, 209223.

77. Bailey SR, Baillon ML, Rycroft AN, et al. (2003) Identification of equine cecal bacteria producing amines in an in vitro model of carbohydrate overload. Appl Environ Microbiol 69, 2087-2093.

78. Cani PD \& Delzenne NM (2011) The gut microbiome as therapeutic target. Pharmacol Ther 130, 202-212.

79. Patel MS, Owen OE, Goldman LI, et al. (1975) Fatty acid synthesis by human adipose tissue. Metabolism 24, 161-173.

80. Tremaroli V \& Backhed F (2012) Functional interactions between the gut microbiota and host metabolism. Nature 489, 242-249.

81. Farningham DA \& Whyte CC (1993) The role of propionate and acetate in the control of food intake in sheep. BrJ Nutr 70, 37-46.

82. Sheperd AC \& Combs DK (1998) Long-term effects of acetate and propionate on voluntary feed intake by midlactation cows. J Dairy Sci 81, 2240-2250.

83. Simmons HA \& Ford EJ (1991) Gluconeogenesis from propionate produced in the colon of the horse. Br Vet J 147, 340-345.

84. Baker JP, Sutton HH, Lieb S, et al. (1970) Portal and carotid catheterization of the equine. J Anim Sci 31, 502-508.

85. Shinkai T, Ohji R, Matsumoto N, et al. (2009) Fibrolytic capabilities of ruminal bacterium Fibrobacter succinogenes in relation to its phylogenetic grouping. FEMS Microbiol Lett 294, 183-190.

86. Kobayashi Y, Shinkai T \& Koike S (2008) Ecological and physiological characterization shows that Fibrobacter succinogenes is important in rumen fiber digestion - review. Folia Microbiol (Praha) 53, 195-200.

87. Suen G, Weimer PJ, Stevenson DM, et al. (2011) The complete genome sequence of Fibrobacter succinogenes S85 reveals a cellulolytic and metabolic specialist. PLoS ONE 6, e18814.

88. Mullins CR, Mamedova LK, Carpenter AJ, et al. (2013) Analysis of rumen microbial populations in lactating dairy cattle fed diets varying in carbohydrate profiles and Saccharomyces cerevisiae fermentation product. J Dairy Sci 96, 5872-5881.

89. Cao H \& Shockey JM (2012) Comparison of TaqMan and SYBR Green qPCR methods for quantitative gene expression in tung tree tissues. J Agric Food Chem 60, 12296-12303. 
90. Malinen E, Kassinen A, Rinttila T, et al. (2003) Comparison of real-time PCR with SYBR Green I or 5'-nuclease assays and dot-blot hybridization with rDNA-targeted oligonucleotide probes in quantification of selected faecal bacteria. Microbiology 149, 269-277.

91. Lee PK, Macbeth TW, Sorenson KS Jr, et al. (2008) Quantifying genes and transcripts to assess the in situ physiology of "Debalococcoides" spp. in a trichloroethene-contaminated groundwater site. Appl Environ Microbiol 74, 2728-2739.

92. Perez-Osorio AC, Williamson KS \& Franklin MJ (2010) Heterogeneous rpoS and rhlR mRNA levels and 16S rRNA/
rDNA (rRNA gene) ratios within Pseudomonas aeruginosa biofilms, sampled by laser capture microdissection. J Bacteriol 192, 29913000.

93. Pagan J (1998) Measuring the Digestible Energy Content of Horse Feeds. Nottingham: Nottingham University Press.

94. De Gregoris TB, Aldred N, Clare AS, et al. (2011) Improvement of phylum- and class-specific primers for real-time PCR quantification of bacterial taxa. J Microbiol Methods 86, 351-356.

95. Nadkarni MA, Martin FE, Jacques NA, et al. (2002) Determination of bacterial load by real-time PCR using a broad-range (universal) probe and primers set. Microbiology 148, 257-266. 